\title{
Short-term effects of experimental trampling on polychaetes of a rocky intertidal substratum (Asinara Island MPA, NW Mediterranean)
}

\author{
DANIELA CASU ${ }^{1,2}$, GIULIA CECCHERELLI ${ }^{3}$, MARCO CURINI-GALLETTI $^{1}$ \\ and ALBERTO CASTELLI ${ }^{2}$ \\ ${ }^{1}$ Dipartimento di Zoologia e Genetica Evoluzionistica, University of Sassari, C.so Margherita di Savoia, 15, \\ 07100 Sassari, Italy. E-mail: danicasu@uniss.it \\ Dipartimento di Biologia, University of Pisa, Via Volta, 6, 56126 Pisa, Italy. \\ ${ }^{3}$ Dipartimento di Botanica e Ecologia Vegetale, University of Sassari, Via Muroni, 25, 07100 Sassari, Italy.
}

\begin{abstract}
SUMMARY: Rocky intertidal platforms at Asinara Island Marine Protected Area (Italy, Mediterranean Sea) were experimentally trampled to assess the impact of human visitation on polychaetes. Trampling at two different experimental intensities $(60,120$ steps/20x20 cm quadrat) and controls were applied at two locations ("no-entry, no-take" zones) of the MPA. One day after the experimental trampling, benthic samples were collected and the polychaetes counted and identified. Overall 1146 individuals were collected; Salvatoria clavata, Polyophthalmus pictus, Syllis prolifera, Amphiglena mediterranea, Fabricia stellaris, Platynereis dumerilii and Sphaerosyllis taylori were the most abundant species. Analyses of variance on all polychaetes and on each of the important polychaete species showed a significant higher abundance in controls than in trampled plots. Given the short-term decline in abundance, these results suggest that polychaetes are vulnerable even to the lowest experimental level of trampling.
\end{abstract}

Keywords: polychaetes, NW Mediterranean, MPA, Asinara Island.

RESUMEN: EFECTOS A CORTO PLAZO DE UN PISOTEADO EXPERIMENTAL SOBRE LAS POBLACIONES DE POLIQUETOS QUE HABITAN

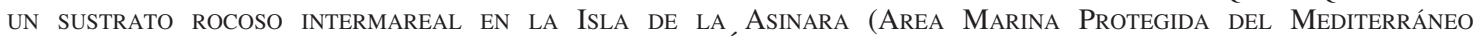
NOROCCIDENTAL). Las plataformas rocosas intermareales del Área Marina Protegida (AMP) de la Isla de la Asinara (Cerdeña, Italia), fueron experimentalmente pisoteadas para evaluar el impacto de la presencia humana sobre las comunidades de poliquetos. Se aplicaron dos diferentes intensidades experimentales $(60,120$, pasos sobre una superficie de $20 \times 20 \mathrm{~cm})$ y control en dos zonas (zonas definidas como "no-entry, no-take") de la AMP. Un día después de la perturbación experimental, se recogían muestras bentónicas identificando y cuantificando los poliquetos. Un total de 1.146 poliquetos fueron recogidos; Salvatoria clavata, Polyophthalmus pictus, Syllis prolifera, Amphiglena mediterranea, Fabricia stellaris, Platynereis dumerilii y Sphaerosyllis taylori fueron las especies más abundantes. El análisis de la variación global de los poliquetos y de sus especies permitieron observar una abundancia significativamente superior en las áreas de control que en las parcelas pisoteadas. Considerando en el corto plazo la disminuciòn de la abundancia, estos resultados sugieren que los poliquetos son vulnerables, includo en el nivel experimental más bajo probado.

Palabras clave: poliquetos, NW Mediterráneo, AMP, Isla de la Asinara.

\section{INTRODUCTION}

The wide range of anthropogenic disturbances influencing marine coastal assemblages is of increasing concern. Rocky intertidal communities are particularly sensitive to disturbance from indirect agents, such as sewage and industrial effluents (Littler and Murray, 1975), and to more direct agents, such as harvesting and trampling (Duran and Castilla, 1989; Underwood and Kennelly, 1990; 
Povey and Keough, 1991; Murray et al., 1999). Several studies have documented that these impacts affect the intertidal target species by inducing changes in abundance, decreasing species richness and shifting community composition (Siegfried et al., 1985, Keough et al., 1993, Dye et al., 1997; Fernandez and Castilla, 1997; Lasiak, 1998).

Trampling is an important ecological phenomenon on many shores, and its effects, when intensive, may significantly contribute to local changes in the composition of marine communities. On rocky shores, trampled areas generally have lower species diversity and density of sessile organisms than in less disturbed areas. Several types of impact are associated with trampling such as direct mortality or dislodgment of organisms, weakening of algal holdfasts and structural damage, resulting in both increased vulnerability of rocky communities to other abiotic (e.g. dessication) or biotic (e.g. predation) factors, and habitat loss, as sessile organisms are crushed or removed (Brosnan and Crumrine, 1994; Brown and Taylor, 1999).

Most of the research has been focused on large conspicuous organisms (e.g. Povey and Keough, 1991; Brosnan and Crumrine, 1994; Keough and Quinn, 1998). However, smaller cryptic targets may also deserve attention due to their high abundance (Hicks, 1986) and productivity (Edgar and Moore, 1986), and their utility as food for higher trophic levels (Coull and Wells, 1983; Jones, 1988). In rocky intertidal habitats, highest densities of small animals are typically found on macro-algae (Gibbons and Griffiths, 1986), which provide epifauna with a range of resources, such as food, and refuge from predation and dessication (Gibbons, 1991). Several studies carried out in shallow water revealed that canopy-forming macroalgae may be badly damaged by human trampling, showing a rapid decrease in canopy cover (Povey and Keough, 1991; Brosnan and Crumrine, 1994; Schiel and Taylor, 1999; Milazzo et al., 2002). Epifaunal abundance is therefore likely to be reduced where human trampling reduces the biomass of their hosting algae.

The Asinara Island Marine Protected Area (MPA) (41 $\left.{ }^{\circ} 03{ }^{\prime} 58^{\prime \prime} \mathrm{N} 8^{\circ} 15^{\prime} 57^{\prime \prime} \mathrm{E}\right)$ in Sardinia (Italy) was a prison island until 1997 and public access has been forbidden for nearly a century. This has led to the maintenance of a specific Mediterranean flora and fauna and has prevented serious damage to the coastal marine assemblages (Villa et al., 2002). For this reason, in recent years, this MPA has become a tourist attraction and human presence, where allowed, may conflict with conservation goals (Eckrich and Holmquist, 2000).

In the present study we examined the immediate effects of experimental human trampling on polychaetes inhabiting intertidal hard-bottom habitats covered by algae within two "no-entry, no-take" sites at the Asinara Island MPA.

\section{MATERIALS AND METHODS}

The study was carried out in late August 2002 within the integral reserve of the Asinara Island MPA, on two eastern rocky shore locations called Cala Arena and Cala Sant'Andrea (Fig. 1). At each location, six experimental areas within a platform covered by photophilous mixed erect algal assemblages were randomly chosen between 0.2-0.4 m water depth.

Two different experimental intensities of trampling (60 and 120 steps $/ 20 \times 20 \mathrm{~cm}$ quadrat) and controls (no trampling) were applied to the quadrats. Estimates of trampling intensities to apply in the experiment were derived from observation of visitors at the MPA during the summer peak period (Casu, 2004). Each non-control quadrat was entirely trampled by a person $\sim 60 \mathrm{Kg}$ in weight and wearing rubber-soled shoes. At each location, two replicate quadrats were randomly assigned to the three trampling levels, and two replicate samples were collected within each quadrat. Replication of the experiment as well as the size of the corer used for sampling were decided on the basis of a pilot study and a cost-benefit analysis (Casu et al., 2004).

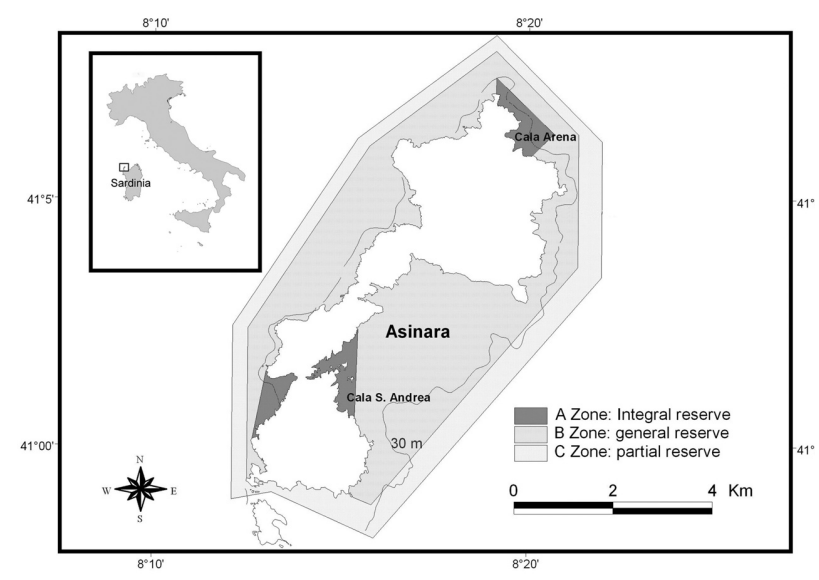

FIG. 1. - Map of the study locations. Delimited sectors along the coastline identify the zones at different protection level within the Asinara MPA 
One day after the experimental trampling, benthic samples were collected using plastic cylinders of $40 \mathrm{~mm}$ inner diameter, corresponding to $12.56 \mathrm{~cm}^{2}$ in surface scraped area (Brown and Taylor, 1999). In the field algae and benthic invertebrates were removed down to the basal crust using a metal scraper and preserved in $4 \%$ formalin in seawater. In the laboratory, the polychaetes were sieved through a 100-mm mesh, counted, and identified.

Analysis of similarities (1-way ANOSIM, Clarke, 1993) was performed on overall abundance of polychaete species to test for differences among the three different levels of trampling. To identify all "important" taxa, the percentage contribution of each polychaete species to the average dissimilarity among treatments was calculated using SIMPER (Clarke, 1993). Non-metric multidimensional scaling (nMDS) was used to produce two-dimensional ordination plots to show similarities among polychaete assemblages at different trampling intensities at the two sites. Analysis was performed using the Bray-Curtis similarity coefficient (Bray and Curtis, 1957) on untransformed data. All analyses were carried out using the PRIMER 5 programme (Plymouth Marine Laboratory, UK).

Three-way ANOVAs were performed to test hypotheses about differences in the abundance of polychaetes among different levels of trampling. These analyses were preceded by Cochran's test for homogeneity of variances (Winer et al., 1991 Underwood, 1997). 'Location' (Cala Arena and Cala Sant' Andrea) was treated as random and 'Trampling' was treated as fixed factor ( 0 which served as control, 60 and 120 footfalls/quadrat): they both were orthogonal, while 'area' was random and nested in location (2 levels). Cochran's test was used to check for the homogeneity of variances (Winer, 1971). Whenever necessary data were transformed. Student-Newman-Keuls (SNK) test was used for a posteriori comparison of the means when appropriate (Underwood, 1997). This analysis was carried out using the GMAV 5.0 software (University of Sydney).

\section{RESULTS}

Overall, 1,146 polychaetes, belonging to 37 species and 13 families (Table 1), were collected. Dominant families were Syllidae (569), Sabellidae (191) and Opheliidae (162). As is usually the case in
TABLE 1. - Taxonomic list of the recorded polychaete species

SPIONIDAE

Polydora sp.

Spio decoratus Bobretzky, 1870

CIRRATULIDAE

Caulleriella bioculata (Keferstein,1862)

CAPITELLIDAE

Capitella cf capitata

OPHELIIDAE

Polyophthalmus pictus (Dujardin,1839)

HESIONIDAE

Ophiodromus pallidus (Claparède, 1864)

SYLLIDAE

Odontosyllis ctenostoma Claparède, 1868

Syllides convolutus Webster \& Benedict, 1884

Exogone dispar Webster, 1879

Exogone naidina Oersted, 1845

Exogone verugera Claparède, 1868

Salvatoria clavata (Claparède, 1863)

Parapionosyllis elegans (Pierantoni,1903)

Parapionosyllis minuta (Pierantoni,1903)

Sphaerosyllis austriaca Banse, 1959

Sphaerosyllis cryptica Ben-Eliahu, 1977

Sphaerosyllis hystrix Claparède, 1863

Sphaerosyllis pirifera Claparède, 1868

Sphaerosyllis taylori Perkins, 1981

Ehlersia ferruginea (Langerhans, 1881)

Syllis bouvieri Gravier, 1900

Syllis prolifera (Krohn, 1852)

Syllis truncata cryptica Ben-Eliahu, 1977

Syllis variegata Grube, 1860

Syllis sp. 1

NEREIDIDAE

Platynereis dumerilii (Audouin \& Milne-Edwards, 1833)

CHRYSOPETALIDAE

Chrysopetalum debile (Grube, 1855)

EUNICIDAE

Eunice vittata (Delle Chiaje, 1828)

Lysidice ninetta (Audouin \& Milne-Edwards, 1833

DORVILLEIDAE

Dorvillea rubrovittata (Grube, 1855)

TEREBELLIDAE

Pista cristata (O.F. Muller, 1776)

SABELLIDAE

Fabricia stellaris (O.F. Muller, 1774)

Amphiglena mediterranea (Leydig, 1851)

Chone collaris Langerhans, 1880

Chone duneri Malmgren, 1867

SERPULIDAE

Serpula sp. 1

hard intertidal and upper subtidal bottoms (Abbiati et al., 1987) Syllidae was the richest family, in both numbers of species (19) and individuals. Salvatoria clavata, Polyophthalmus pictus, Syllis prolifera, Amphiglena mediterranea, Fabricia stellaris, and Platynereis dumerilii (Fig. 2) were the most abundant species. Overall at the sites, Corallina elongata Ellis et Solander, Ceramium diaphanum (Lightf.) Roth, Polysiphonia opaca (C. Agardh) Moris et De Not, Stypocaulon scoparium (L.) Sauv, Dasycladus vermicularis (Scopoli) Krasser, Jania rubens (L.), Padina pavonica L. Lamour, were the most common algal species found on the platforms.

Twenty-four hours after the experimental trampling, polychaetes showed a great susceptibility to 

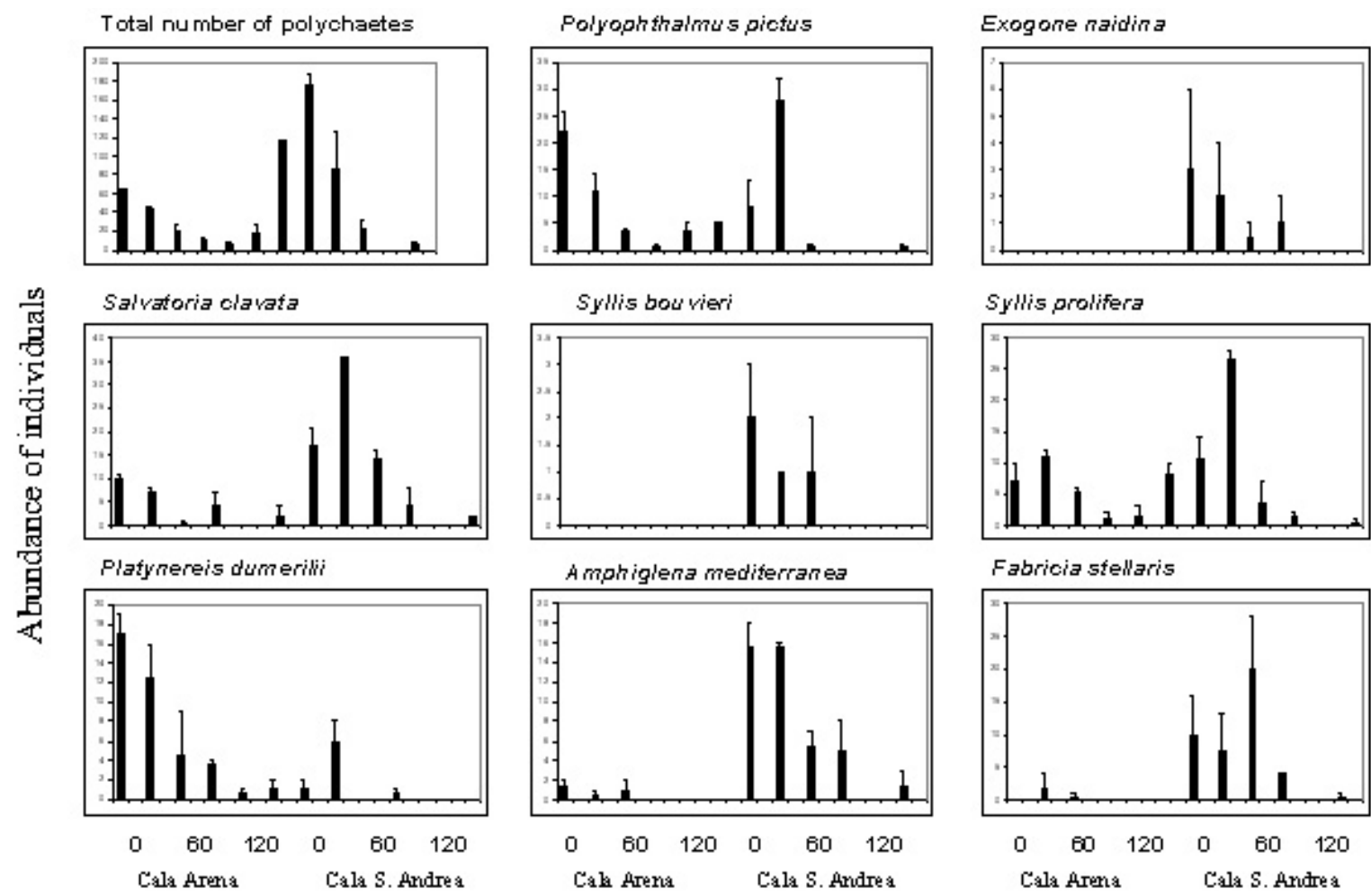

Syllis prolifera
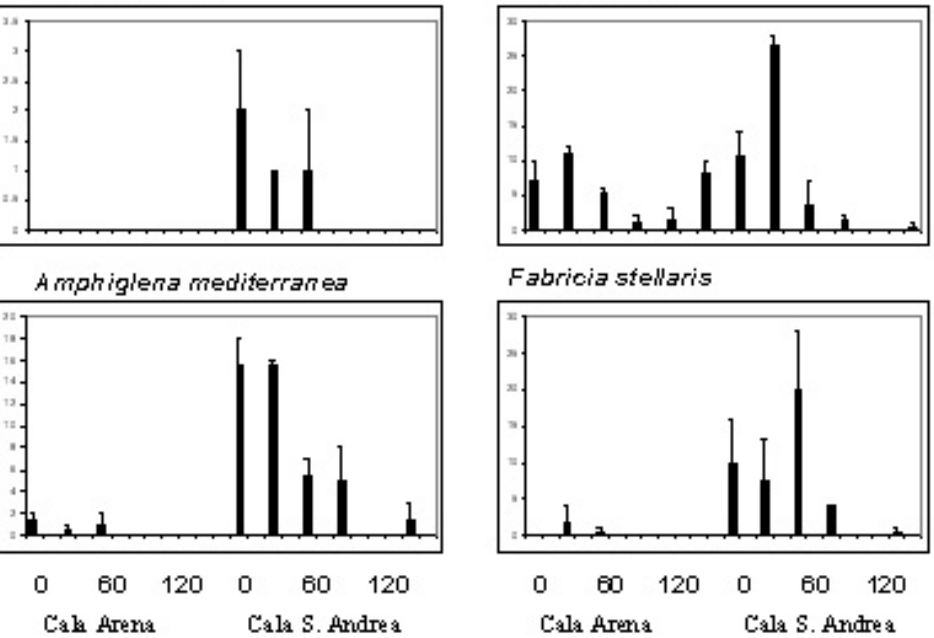

FIG. 2. - Mean abundance (+SE) of overall polychaetes and each of the important polychaete species sampled at control (0) and at different trampling intensities (60 and 120 steps/quadrat); areas $(n=2)$.

physical disturbance. The analysis of similarity revealed significant differences in abundance of polychaetes among the different levels of trampling (ANOSIM, $\mathrm{R}=0.384 \mathrm{p}=0.1 \%$ ). This is also indicated by the spread of the replicate samples for each site

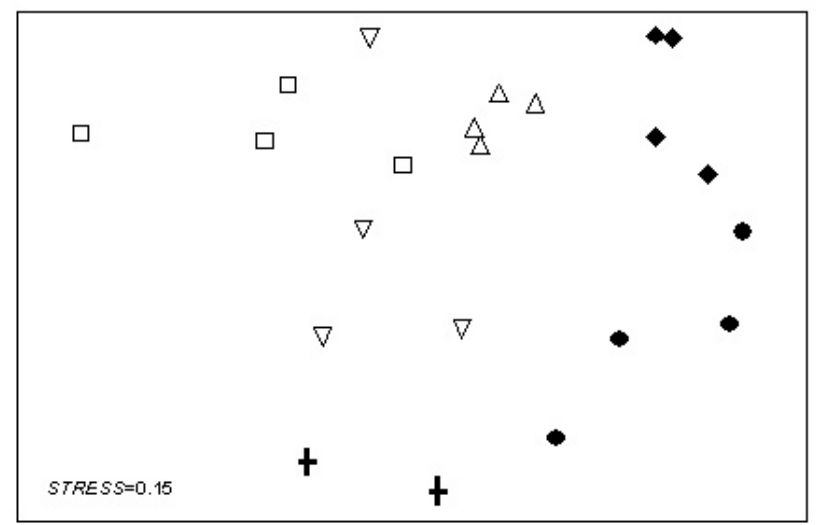
$\triangle$ CALA ARENAO
- calas. andrea o
$\nabla$ CALA ARENA 60
- calas. andrea 60
$\square \quad$ CALA ARENA 120
+ calas. andrea 120

FIG. 3. - Non-metric Multidimensional Scaling plots comparing polychaete assemblages at the two sites (Cala Arena and Cala S. Andrea) at controls (0) and at different trampling intensities (60 and 120 steps/quadrat). in the nMDS ordination plot (Fig. 3). The pair-wise comparisons (Table 2) showed lower abundance of polychaetes in trampled plots than in controls independently of intensities $(0-60 \mathrm{p}=0.6 \% ; 0-120$ $\mathrm{p}=0.1 \% 60-120 \mathrm{p}=5.5 \%)$. SIMPER analysis identified polychaete species that mostly contributed to the average dissimilarities (Table 3).

Analyses of variance on overall polychaete abundance identified a significantly higher abundance in controls than in trampled plots (Table 4 and Table 5). Among the most important polychaete species contributing to the average dissimilarities among treatments, Polyophthalmus pictus, Exogone naidina, Salvatoria clavata, Syllis bouvieri, Syllis prolifera, Platynereis dumerilii and Amphiglena mediterranea were more abundant in controls than in tram-

TABLE 2. $-R$ values from one-way analysis of similarity (ANOSIM) comparing the effect of three different trampling intensities on over all abundance of polychaetes. $\mathrm{R}=0.384 ; \mathrm{P}=0.1 \%$.

\begin{tabular}{lcc} 
Trampling intensities & Statistic value & Significance level \% \\
\hline $0-60$ & 0.373 & 0.6 \\
$0-120$ & 0.629 & 0.1 \\
$60-120$ & 0.195 & 5.5 \\
\hline
\end{tabular}


TABLE 3. - Relative contribution of polychaete species to dissimilarities among trampling intensities at each site (cut off for low contributions $90 \%)$.

\begin{tabular}{|c|c|c|c|}
\hline \multicolumn{2}{|l|}{$\begin{array}{l}\text { Cala Arena } \\
0-60\end{array}$} & \multicolumn{2}{|l|}{$0-120$} \\
\hline $\begin{array}{l}\text { Polyophthalmus pictus } \\
\text { Platynereis dumerilii } \\
\text { Syllis prolifera } \\
\text { Salvatoria clavata } \\
\text { Parapionosyllis elegans } \\
\text { Fabricia stellaris }\end{array}$ & $\begin{array}{r}31.49 \\
24.34 \\
14.75 \\
13.83 \\
4.05 \\
2.87\end{array}$ & $\begin{array}{l}\text { Platynereis dumerilii } \\
\text { Polyophthalmus pictus } \\
\text { Salvatoria clavata } \\
\text { Syllis prolifera } \\
\text { Sphaerosyllis pirifera }\end{array}$ & $\begin{array}{r}31.59 \\
26.42 \\
17.07 \\
13.20 \\
2.73\end{array}$ \\
\hline $\begin{array}{l}\text { Cala S. Andrea } \\
0-60\end{array}$ & & $0-120$ & \\
\hline $\begin{array}{l}\text { Salvatoria clavata } \\
\text { Polyophthalmus pictus } \\
\text { Sphaerosyllis taylori } \\
\text { Syllis prolifera } \\
\text { Serpula sp1 } \\
\text { Amphiglena mediterranea } \\
\text { Fabricia stellaris } \\
\text { Parapionosyllis elegans } \\
\text { Sphaerosyllis cryptica } \\
\text { Sphaerosyllis hystrix } \\
\text { Platynereis dumerilii } \\
\text { Syllis sp1 } \\
\text { Exogone naidina } \\
\text { Parapionosyllis minuta } \\
\text { Sphaerosyllis austriaca } \\
\text { Syllis bouvieri }\end{array}$ & $\begin{array}{r}12.33 \\
11.68 \\
11.66 \\
11.01 \\
10.66 \\
7.63 \\
5.90 \\
4.24 \\
3.33 \\
2.65 \\
2.12 \\
1.91 \\
1.90 \\
1.76 \\
1.23 \\
1.05\end{array}$ & $\begin{array}{l}\text { Salvatoria clavata } \\
\text { Syllis prolifera } \\
\text { Sphaerosyllis taylori } \\
\text { Polyophthalmus pictus } \\
\text { Serpula sp1 } \\
\text { Amphiglena mediterranea } \\
\text { Fabricia stellaris } \\
\text { Sphaerosyllis cryptica } \\
\text { Sphaerosyllis hystrix } \\
\text { Platynereis dumerilii } \\
\text { Exogone naidina } \\
\text { Syllis sp } \\
\text { Parapionosyllis elegans }\end{array}$ & $\begin{array}{r}16.44 \\
11.96 \\
1.21 \\
11.18 \\
10.99 \\
10.19 \\
6.07 \\
3.50 \\
2.48 \\
2.14 \\
1.93 \\
1.84 \\
1.31\end{array}$ \\
\hline
\end{tabular}

TABLE 4. - Results of ANOVAs of the effects of location, trampling ( 0,60 and 120 steps/quadrat) and area on the overall abundance of polychaetes and each of the important polychaete species.* $\mathrm{p}<0.05$

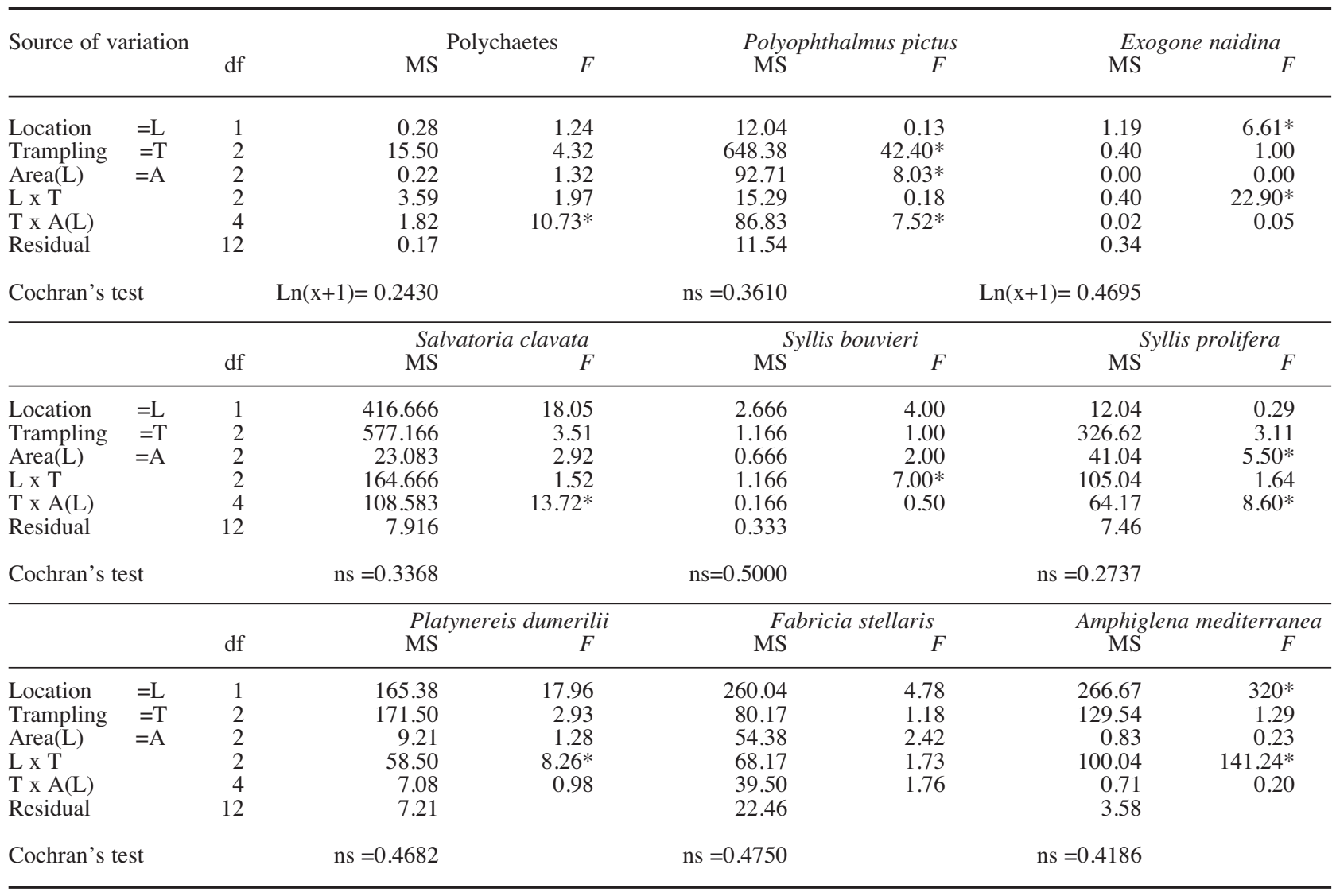


TABLE 5. - Results of SNK tests on trampling intensities for overall abundance of polychaetes and each of the important polychaete species. $\mathrm{T}=$ Trampling, $\mathrm{L}=$ Location, $\mathrm{A}=$ Area.

\begin{tabular}{|c|c|c|c|c|c|c|c|}
\hline \multicolumn{2}{|l|}{ Polychaetes } & \multicolumn{2}{|c|}{ Polyophthalmus pictus } & \multicolumn{2}{|c|}{ Exogone naidina } & \multicolumn{2}{|c|}{ Salvatoria clavata } \\
\hline $\begin{array}{l}\mathrm{SE}=0.2430 \\
\mathrm{~T} \times \mathrm{A}(\mathrm{L})\end{array}$ & $\begin{array}{l}\text { Cala Arena } \\
0>60>120 \\
0>60=120 \\
\text { Cala } S \text {. Andrea } \\
0=60>120 \\
0>60>120\end{array}$ & $\begin{array}{l}\mathrm{SE}=2.4023 \\
\mathrm{~T} \times \mathrm{A}(\mathrm{L})\end{array}$ & $\begin{array}{l}\text { Cala Arena } \\
0>60=120 \\
0=60=120 \\
\text { Cala } S \text {. Andrea } \\
0=60=120 \\
0>60=120\end{array}$ & $\begin{array}{l}\mathrm{SE}=0 . \\
\mathrm{L} \times \mathrm{T}\end{array}$ & $\begin{array}{l}\text { Cala Arena } \\
0=60=120 \\
\text { Cala S. Andrea } \\
0>60>120\end{array}$ & $\begin{array}{l}\mathrm{SE}=1.9896 \\
\mathrm{~T} \times \mathrm{A}(\mathrm{L})\end{array}$ & $\begin{array}{l}\text { Cala Arena } \\
0>60=120 \\
0=60=120 \\
\text { Cala S. Andrea } \\
0=60>120 \\
0>60=120\end{array}$ \\
\hline Syllis bouvier & & Syllis prolif & & Platyn & dumerilii & Amphiglen & mediterranea \\
\hline $\begin{array}{l}\mathrm{SE}=0.2041 \\
\mathrm{~L} \times \mathrm{T}\end{array}$ & $\begin{array}{l}\text { Cala Arena } \\
0=60=120 \\
\text { Cala S. Andrea } \\
0>60=120\end{array}$ & $\begin{array}{l}\mathrm{SE}=0.1 .931 \\
\mathrm{~T} \times \mathrm{A}(\mathrm{L})\end{array}$ & $\begin{array}{l}\text { Cala Arena } \\
0=60=120 \\
0=60>120 \\
\text { Cala S. Andrea } \\
0>60=120 \\
0>60=120\end{array}$ & $\begin{array}{l}\mathrm{SE}=1 . \\
\mathrm{L} \times \mathrm{T}\end{array}$ & $\begin{array}{l}\text { Cala Arena } \\
0>60=120 \\
\text { Cala S. Andrea } \\
0=60=120\end{array}$ & $\begin{array}{l}\mathrm{SE}=0.4208 \\
\mathrm{~L} \times \mathrm{T}\end{array}$ & $\begin{array}{l}\text { Cala Arena } \\
0=60=120 \\
\text { Cala S. Andrea } \\
0>60>120\end{array}$ \\
\hline
\end{tabular}

pled areas (Table 4 and Table 5). The null hypothesis was that the abundance of polychaete species collected was the same at different trampling intensities and controls, however, between the two trampling levels (60 and 120), an alternative hypothesis (SNK Tests) could not be identified (Table 5). Results for Fabricia stellaris showed no effects of trampling (Table 4).

For some species, significant differences were found between locations (Exogone naidina, Amphiglena mediterranea) and areas (Polyophthalmus pictus, Syllis prolifera). Variation in abundance of some polychaete species (Parapionosyllis elegans, P. minuta, Sphaerosyllis austriaca, S. cryptica, S. hystrix, S. taylori, S. pirifera, Syllis sp1, Serpula sp1) could not be analyzed by ANOVA because of variance heterogeneity, even after data transformation.

\section{DISCUSSION}

Polychaetes occurring in Asinara Island MPA shallow waters revealed high vulnerability to experimental human trampling, which caused immediate declines in abundance of the total number of individuals. Trampling reduces densities of algaedwelling animals due to the direct effect of the crushing impact of the footsteps. Also, algal loss due to fragmentation may increase susceptibility of the remaining organisms to other abiotic and biotic factors such as dessication and predation (Brosnan and Crumrine, 1994; Schiel and Taylor, 1999).
Effects of trampling were variable among polychaete species: disturbance caused immediate decrease in density of polychaete species inhabiting photophilous algae assemblages, such as Polyophthalmus pictus, Exogone naidina, Salvatoria clavata, Syllis bouvieri, Syllis prolifera, Platynereis dumerilii and Amphiglena mediterranea (San Martin, 1984; Cantone and Fassari, 1986; Sardà, 1991; Lopez and Vieitez, 1999; Tena et al., 2000, Çinar, 2003; Giangrande et al., 2003).

Moreover, if direct impact of trampling caused a subsequent shift in community composition, vulnerability of individual taxa would be related to their morphology and ecology (Brosnan and Crumrine, 1994; Brown and Taylor, 1999). Differences between similar species such as the two small sabellids Fabricia stellaris, which did not respond to trampling, and Amphiglena mediterranea, which, conversely, is significantly reduced in abundance by experimental trampling, are probably related to the different ecological requirement of these two species (Gillandt, 1979; Tena et al., 2000). However, effects of trampling on mobile polychaetes are difficult to assess in this experiment due to the small spatial scale: these polychaetes could have easily moved away from the trampled quadrats after trampling and before sampling. Other trampling studies have demonstrated little direct reduction of mobile animals such as gastropods (Povey and Keough, 1991).

Subtidal habitats adjacent to sampled platforms have mostly sandy bottoms. Wave action, depending on site exposure and wind direction, traps the sedi- 
ment on platforms among algae thus contributing to the substratum, allowing for the settlement of interstitial polychaete species, such as Parapionosyllis spp. (Abbiati et al., 1987, Giangrande 1988; Somaschini et al., 1994). In such a case, it is more likely that trampling effects are indirect, through changes to the habitat itself. Algal vulnerability to trampling is likely to depend on their morphology (Milazzo et al., 2002). This feature can also be the reason for spatially significant differences in some polychaete species, found at both spatial scales (locations and areas).

Tolerance and recovery capabilities are crucial features in any disturbed benthic assemblage and are strictly related not only to the community structure but also to the type, magnitude and frequency of the occurring disturbance (Underwood, 1989; Schiel and Taylor, 1999). The present experiment, with trampling performed only once at two different intensities, could be referred too as a "pulse" disturbance, whereas other studies are designed to accomplish a "press" disturbance, where species are repeatedly impacted over long periods (Beauchamp and Gowing, 1982; Castilla and Duran, 1985; Povey and Keough, 1991, Brosnan and Crumrine, 1994). Recovery is likely to be related not only to the reduction or cessation of pulse disturbances but also to the time necessary to allow recruitment and growth processes (Schiel and Taylor, 1999). Pulse and press disturbances are highlighted by changes in polychaete assemblages because the presence of mobile and sessile organisms, generally results in a decrease in abundance and diversity.

The biodiversity of rocky intertidal zones, especially in MPAs, also depends on a wide range of other human recreational activities. The risk is that, without proper management, those activities could increasingly contribute to degradation of intertidal areas. MPAs could play a major role in safeguarding resident flora and fauna by establishing specific controlled areas, where many rocky intertidal organisms could benefit from limited human access (Agardy, 1997; Murray et al., 1999)

\section{ACKNOWLEDGEMENTS}

We are sincerely grateful to David Pala for valuable assistance in the field and the whole staff of the Asinara Island National Park for support and assistance. We also thank Francesca Madrau for improv- ing the English in an earlier version of the manuscript. This study is part of Daniela Casu's Ph.D. thesis.

\section{REFERENCES}

Abbiati, M., C.N. Bianchi and A. Castelli. - 1987. Polychaete vertical zonation along a littoral cliff in the Western Mediterranean. PSZNI: Mar. Ecol., 8: 33-48.

Agardy, M.T. - 1997. Marine protected areas and ocean conservation. Academic press, San Diego.

Beauchamp, K.A. and M.M. Gowing. - 1982. A quantitative assessment of human trampling effects on a rocky intertidal community. Mar. Environ. Res., 7: 279-293.

Bray, J.R. and J.T. Curtis. - 1957. An ordination of the upland forest communities of Southern Wisconsin. Ecol. Monogr., 27: 325-349.

Brosnan, D.M. and L.L. Crumrine. - 1994. Effects of human trampling on marine rocky shore communities. J. Exp. Mar. Biol. Ecol., 177: 79-97.

Brown, P.J. and R.B. Taylor. - 1999. Effects of trampling by humans on animals inhabiting coralline algal turf in the rocky intertidal. J. Exp. Mar. Biol. Ecol., 235: 45-53.

Cantone, G. and G. Fassari. - 1986. Variazioni qualitative e quantitative di un popolamento a policheti nei fondi duri della rada di Augusta. Animalia, 13: 203-216.

Castilla, J.C. and L.R. Duràn. - 1985. Human exclusion from the rocky intertidal zone of central Chile. The effects on Concholepas concholepas (Gastropoda). Oikos, 45: 391-399.

Casu, D. - 2004. Conservazione e fruizione in Aree Marine Protette della Sardegna settentrionale: un approccio basato sull'analisi delle comunità bentoniche. $\mathrm{Ph} . \mathrm{D}$. Thesis, University of Sassari.

Casu, D., G. Ceccherelli, and A. Castelli. - 2004. Spatial distribution of small benthic invertebrates in rocky upper infralittoral at the Asinara Island (NW Mediterranean): a pilot study. Vie Milieu, 54: 239-245.

Çinar, M.E. - 2003. Ecology of Syllidae (Annelida: polychaeta) from northern Cyprus (Eastern Mediterranean Sea). Bull. Mar. Sci., 72: 795-811

Clarke, K.R. 1993. - Non parametric multivariate analyses of changes in community structure. Aust. J. Ecol., 18: 117-143.

Coull, B.C. and J.B.J. Wells. - 1983. Refuges from fish predation: experiments with phytal meiofauna from the New Zealand rocky intertidal. Ecology, 64: 1599-1609.

Duran, L.R. and J.C. Castilla. - 1989. Variation and persistence of the middle rocky intertidal community of central Chile, with and without human harvesting. Mar. Biol., 103: 555-562.

Dye, A.H., T.A. Lasiak and S. Gabula. - 1997. Recovery and recruitment of the brown mussel, Perna perna (L.), in Transkei: implications for management. S. Afr. J. Zool., 32: 118-123.

Eckrich, C.E. and J.G. Holmquist. - 2000. Trampling in a seagrass assemblage: direct effects, response of associated fauna, and the role of substrate characteristics. Mar. Ecol. Progr. Ser., 201: 199-209.

Edgar, G.J., and P.G. Moore. - 1986. Macro-algae as habitat for motile macrofauna. Monogr. Biol., 4: 255-277.

Fernandez, M. and J.C. Castilla. - 1997. The Chilean artisanal stone crab (Homalaspis plana) fishery: catch trends in open access zones and the effect of management areas in Central Chile. $J$. Shellfish Res., 16: 371-377.

Giangrande, A. - 1988. Polychaete zonation and its relation to algal distribution down a vertical cliff in the Western Mediterranean (Italy): a structural analysis. J. Exp. Mar. Biol. Ecol., 120: 263276.

Giangrande, A., A.L. Delos, S. Fraschetti, L. Musco, M. Licciano and A. Terlizzi. - 2003. Polychaete assemblages along a rocky shore on the South Adriatic coast (Mediterranean Sea): patterns of spatial distribution. Mar. Biol., 143: 1109-1116.

Gibbons, M.J. - 1991. Rocky shore meiofauna: a brief overview. T. Roy. Soc. S. Afr. 47: 595-603.

Gibbons, M.J. and C.L. Griffiths. - 1986. A comparison of macrofaunal and meiofaunal distribution and standing stock across a 
rocky shore, with an estimate of their productivies. Mar. Biol., 93: 181-188.

Gillandt, L. 1979. Sistematica, autoecologia e biologia dei policheti del littorale roccioso di Helgoland. Mitt. Hamb. Zool. Mus. Inst., 76: 91-92.

Hicks, G.R.F. - 1986. Meiofauna associated with rocky shore algae. In: P.G. Moore and R. Seed (eds.), The ecology of rocky coasts, pp. 36-56. Hodder and Stoughton, London.

Jones, G.P. - 1988. Ecology of rocky reef fish of north-eastern New Zeland: a review. N. Z. J. Mar. Freshw. Res., 22: 445-462.

Keough, M.J., G.P. Quinn and A. King. - 1993. Correlation between human collecting and intertidal mollusc populations on rocky shores. Biol. Conserv., 7: 378-390.

Lasiak, T. - 1998. Multivariate comparisons on rocky intertidal macrofaunal assemblages from replicate exploited and nonexploited localities on the Transkei coast of South Africa. Mar. Ecol.Prog. Ser., 167: 15-23.

Littler, M.M. and S.N. Murray. - 1975. Impact of sewage on the distribution, abundance and community structure of rocky intertidal macro-organisms. Mar. Biol., 30: 277-291.

López, E. and J.M. Viéitez. - 1999. Polychaete assemblages on non-encrusting infralittoral algae from the Chafarinas Islands (SW Mediterranean). Cah. Biol. Mar., 40: 375-384.

Milazzo, M., R. Chemello, F. Badalamenti and S. Riggio. - 2002. Short-term effect of human trampling on the upper infralittoral macroalgae of Ustica Island MPA (western Mediterranean, Italy). J. Mar. Biol. Ass. UK., 82: 745-748.

Murray, S.N., T.G. Denis, J.S. Kido and J.R. Smith. - 1999. Human visitation and the frequency and potential effects of collecting on rocky intertidal populations in southern California marine reserve. Cal. Coop. Oc. Fish. Inv. Rep., 40: 100-106.

Povey, A. and M.J. Keough. - 1991. Effects of trampling on plant and animal populations on rocky shores. Oikos, 61: 355-369.

San Martin, G. - 1984. Estudio biogeografico, faunìstico y sistematico de los poliquetos de la pamilia silidos (Syllidae: Polychaeta) en Baleares. Tesis Doctoral, Univ. Complutense de Madrid.
Sardà, R. - 1991. Polychaete communities related to plant covering in the mediolittoral and infralittoral zones of the Balearic Islands (Western Mediterranean). PSZNI: Mar. Ecol., 12: 341-360.

Schiel, D.R. and D.I. Taylor. - 1999. Effects of trampling on a rocky intertidal algal assemblages in southern New Zealand. $J$. Exp. Mar. Biol. Ecol., 235: 213-235.

Siegfried, W.R., P.A.R. Hockey and A.A. Crowe. - 1985 Exploitation and conservation of brown mussel stocks by coastal people of Transkei. Environ. Conserv., 12: 303-307.

Somaschini, A., M.F. Gravina and G.D. Ardizzone. - 1994. Polychaete depth distribution in a Posidonia oceanica Bed (Rhizome and Matte Strata) and neighboring soft and hard bottoms. PSZNI: Mar. Ecol., 15: 133-151.

Tena, J.R., R. Capaccioni-Azzati, F.J. Torres-Gavila and A.M. Garcia-Carrascosa. - 2000. Polychaetes associated with different facies of the photophilic algal community in the Chafarinas Arcipelago (SW Mediterranean). Bull. Mar. Sci., 67: 55-72.

Underwood, A.J. - 1997. Experiments in ecology. Their logical design and interpretation using analysis of variance. Cambridge University Press, Cambridge.

Underwood, A.J. and S.J. Kennelly. - 1989. Pilot studies for designs of surveys of human disturbances of intertidal habitats in New South Wales. Aust. J. Mar. Freshwat. Res., 41: 165173.

Underwood, A.J. and S.J. Kennelly. - 1990. Pilot studies for designs of surveys of human disturbance of intertidal habitats in New South Wales. Aust. J. Mar. Freshw. Res., 41:165-173.

Villa, F., L. Tunesi and T. Agardy. - 2002. Zoning Marine Protected Areas through Spatial Multiple-Criteria Analysis: the Case of the Asinara Island National Marine Reserve of Italy. Cons. Biol., 16: 515-526.

Winer, B.J. - 1971. Statistical principles in experimental designs, $2^{\text {nd }}$ ed. McGraw-Hill Kogakusha, Tokyo.

Winer, B.J., D.R. Brown and K.M. Michels. - 1991. Statistical principles in experimental design. McGraw-Hill, New York.

Received September 2, 2004. Accepted May 11, 2005. 